\title{
I KONGRES HISTORYKÓW KONSPIRACJI NIEPODLEGŁOŚCIOWEJ
}

W dniach 12-13 XI 2015 r., dla uczczenia Święta Niepodległości oraz 25-lecia istnienia Fundacji Generał Elżbiety Zawackiej odbył się w Toruniu, pod honorowym patronatem Światowego Związku Żołnierzy AK, I Kongres Historyków Konspiracji Niepodległościowej, którego temat przewodni brzmiał: „25 lat niezależnych badań nad konspiracją niepodległościową 1939-1945. Ludzie, instytucje, wydarzenia". Obrady Kongresu poprzedziło spotkanie przy grobie śp. gen. prof. dr hab. Elżbiety Zawackiej na cmentarzu przy ul. Gałczyńskiego w Toruniu. Wyrazem pamięci o Zmarłej były wiązanki kwiatów złożone przez przedstawicieli władz wojewódzkich, miejskich, Instytutu Pamięci Narodowej, organizacji kombatanckich, Biblioteki Pedagogicznej im. gen. bryg. prof. Elżbiety Zawackiej, szkół noszących imię Elżbiety Zawackiej oraz przyjaciół Zmarłej i Fundacji.

Trwający dwa dni Kongres, dotowany przez Gminę Miasta Torun oraz współorganizowany i współfinansowany przez Instytut Pamięci Narodowej i Muzeum II Wojny Światowej w Gdańsku, zgromadził w salach Collegium Humanisticum Uniwersytetu Mikołaja Kopernika w Toruniu (też współorganizatora) licznie przybyłych gości, przyjaciół Fundacji i słuchaczy zainteresowanych tematyką konferencji. Otwarcie Kongresu zainaugurował występ Chóru Dziecięcego „Gioia di Cantare" Zespołu Szkół Muzycznych im. Karola Szymanowskiego w Toruniu, którym dyrygowała Renata Szerafin-Wójtowicz. Przybyłych gości powitał Jan Wyrowiński, przewodniczący Rady Fundacji. W przemówieniach Michał Zaleski, Prezydent Miasta Torunia, dr Łukasz Kamiński, prezes IPN, dr Janusz Marszalec, wicedyrektor Muzeum II Wojny Światowej w Gdańsku, i prof. dr hab. Waldemar Rozynkowski - dyrektor Instytutu Historii i Archiwistyki UMK, podkreślili duże znaczenie dla Torunia i kraju działalności Fundacji założonej przez prof. Elżbietę Zawacką.

W pierwszym dniu obrad Dorota Zawacka-Wakarecy, prezes Zarządu Fundacji, przy współpracy dr Katarzyny Minczykowskiej, zaprezentowała dwudziestopięcioletni dorobek Fundacji Generał Elżbiety Zawackiej, powołanej do życia w 1990 r. jako Fundacja „Archiwum Pomorskie AK", która jest najdłużej działającym w Polsce społecznym archiwum zajmującym się gromadzeniem, opracowywaniem i udostępnianiem materiałów dokumentujących działalność niepodległościową Polaków w latach 1939-1945. Oprócz bogatych i unikalnych zbiorów relacyjnych i fotograficznych Fundacja posiada także duży dorobek wydawniczy. Do 
tej pory wydano 68 tytułów, a publikacje Fundacji są podsumowaniem realizacji jej zadań statutowych, do których należą m.in.: organizowanie konferencji, prelekcji, warsztatów, fundowanie tablic, obelisków i pomników poświęconych żołnierzom AK i Polkom walczącym na wszystkich frontach II wojny światowej. Przeprowadziliśmy 1008 prelekcji, wykładów, warsztatów dla około 22 tys. osób. Za sprawą Fundacji powstało 15 pomników, obelisków i tablic. Prezes Zarządu Fundacji podkreśliła, że dla gen. Elżbiety Zawackiej bardzo ważne było upamiętnienie Polek żołnierzy. Potwierdzeniem tego faktu są dwa ufundowane przez Panią Generał, z własnych funduszy, pomniki: gen. Marii Wittek na dziedzińcu Muzeum Wojska Polskiego w Warszawie (19 IV 2007 r.) i obelisk „Polkom walczącym o wolność i niepodległość Ojczyzny" w Parku Wolności przy Muzeum Powstania Warszawskiego (23 XI 2007 r.). W końcowej części wystąpienia Dorota Zawacka-Wakarecy skierowała serdeczne podziękowania pod adresem instytucji wspierających i finansujących działalność statutową Fundacji.

W dalszej części konferencji referaty i komunikaty wygłosili pracownicy naukowi reprezentujący uczelnie wyższe (Uniwersytet Gdański, Uniwersytet Warszawski, Katolicki Uniwersytet Lubelski, Uniwersytet Papieski im. Jana Pawła II w Krakowie, UMK w Toruniu), Instytut Pamięci Narodowej oraz placówki muzealne. Autorzy referatów, podsumowując dotychczasowy stan wiedzy na temat działalności Polskiego Państwa Podziemnego, wysuwali postulaty badawcze i wskazywali kierunki dalszych badań. Mówiono również o jednym z priorytetowych Centralnych Projektów Badawczych realizowanych przez IPN pn. "Ziemie polskie pod okupacją 1939-1945", którego efektem będą studia i opracowania monograficzne, przynoszące nowe ustalenia i interpretacje, które także wypełnią dostrzeżone luki $\mathrm{w}$ wiedzy na temat okupacji ziem polskich. W kolejnych trzech referatach przedstawiono zaangażowanie Kościoła katolickiego, w tym księży diecezji chełmińskiej, w organizowaniu różnych form oporu przeciw Niemcom i w tajnym nauczaniu. Tematem kilku referatów były powojenne losy żołnierzy AK oraz prace zmierzające do zidentyfikowania zamordowanych i pochowanych w Bydgoszczy przy ul. Kcyńskiej. Zostały również przedstawione wyniki badań ekspedycji archeologicznych i poszukiwawczych grobów żołnierzy AK zamordowanych na terenie Litwy. Prezentując swój dorobek, pracownicy placówek muzealnych z Krakowa, Sztutowa i Warszawy dzielili się doświadczeniami, uwagami oraz mówili o trudnościach, na jakie napotyka historyk w edukacji współczesnego odbiorcy. Zastanawiano się m.in. nad tym, jak pracować, by postać sprzed ponad 70 lat stała się obiektem zainteresowania młodego pokolenia. 
Podczas trwania Kongresu zorganizowano warsztaty historyczne dla uczniów wszystkich typów szkół. Warsztaty prowadzone były przez pracowników Muzeum II Wojny Światowej, Instytutu Pamięci Narodowej i Fundacji, a dotyczyły m.in. wybuchu II wojny światowej, życia codziennego partyzantów, konspiracji pomorskiej, roli dzieci w konspiracji w czasie II wojny światowej, codziennego życia partyzantów. Łącznie w konferencji i warsztatach uczestniczyło ok. 600 osób, w tym ok. 300 wzięło udział w warsztatach historycznych.

I Kongresowi Historyków Konspiracji Niepodległościowej towarzyszyły również wystawy: 1) „Polska walcząca” - przygotowana przez Oddziałowe Biura Edukacji Publicznej IPN w Gdańsku, Delegatura w Bydgoszczy (kurator: Marka Szymaniak); 2) „Okupacja i zbrodnie niemieckie na Kujawach i Pomorzu" - przygotowana przez Biura Edukacji Publicznej IPN w Warszawie (kurator: Paweł Rokicki) oraz ekspozycje Fundacji Generał Elżbiety Zawackiej o działalności Fundacji, prezentujące sylwetki kobiet-żołnierzy oraz eksponaty ze spuścizny Elżbiety Zawackiej.

W zorganizowaniu Kongresu, który spotkał się z dużym zainteresowaniem, wspomagali Fundację: Instytut Pamięci Narodowej, Muzeum II Wojny Światowej w Gdańsku, Wydział Nauk Historycznych oraz Instytut Historii i Archiwistyki Uniwersytetu Mikołaja Kopernika w Toruniu. Pomysłodawcą i koordynatorem przedsięwzięcia była dr Katarzyna Minczykowska.

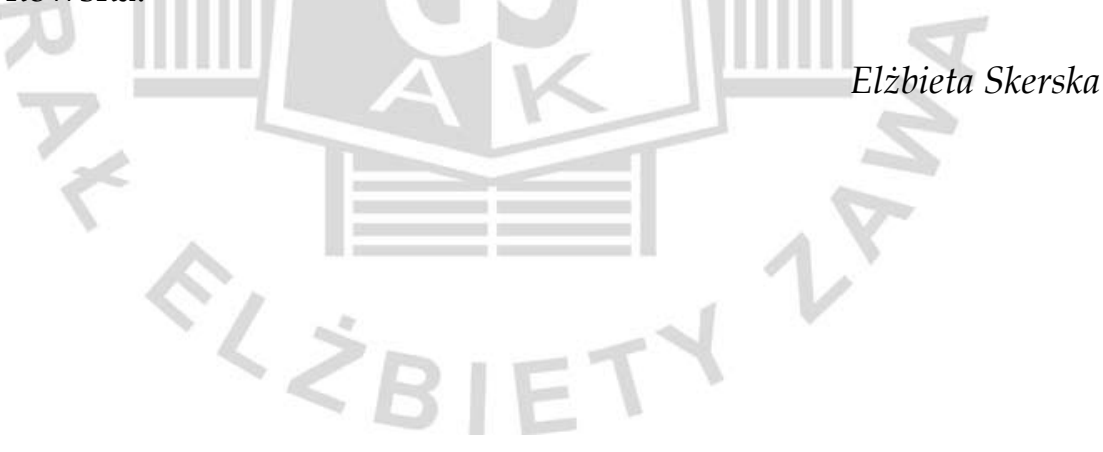

